\title{
Evidence for Britain and Ireland as a linguistic area
}

\section{Supporting online material 1: Linguistic data}

Stefan Dedio ${ }^{1}$, Peter Ranacher ${ }^{2}$, and Paul Widmer ${ }^{1}$

${ }^{1}$ Department of Comparative Linguistics, University of Zurich

${ }^{2}$ Department of Geography, University of Zurich

\section{Contents}

\begin{tabular}{lll}
\hline & Variables & 3
\end{tabular}

\begin{tabular}{|ll|l}
\hline 2 & Insular Celtic & 6
\end{tabular}

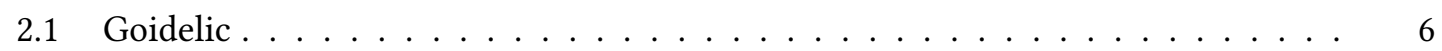

$2.1 .1 \quad$ Old Irish . . . . . . . . . . . . . . . . . . . . . . . . . . . 6

$2.1 .2 \quad$ Middle Irish $\ldots \ldots \ldots \ldots \ldots$

$2.1 .3 \quad$ Modern Irish $\ldots \ldots \ldots \ldots \ldots$

2.1 .4 Scottish Gaelic $\ldots \ldots \ldots \ldots \ldots$

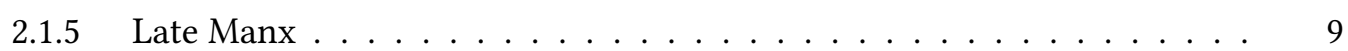

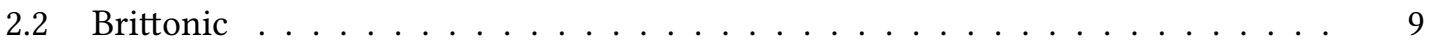

$2.2 .1 \quad$ Middle Welsh $\ldots \ldots \ldots \ldots$

2.2 .2 Northern Welsh $\ldots \ldots \ldots \ldots$

2.2 .3 Southern Welsh . . . . . . . . . . . . . . . . . . . . . . 11

$2.2 .4 \quad$ Middle Breton . . . . . . . . . . . . . . . . . . . . . . . . . . . 12

2.2 .5 Central Breton . . . . . . . . . . . . . . . . . . . . . . . 12

2.2 .6 Middle Cornish . . . . . . . . . . . . . . . . . . . . . . 13

2.2 .7 Late Cornish . . . . . . . . . . . . . . . . . . . . . . . . . . 14

$\begin{array}{lll}3 & \text { Germanic } & 14\end{array}$

3.1 West Germanic . . . . . . . . . . . . . . . . . . . . . . . . . . . . . . . . . . . 14

$3.1 .1 \quad$ Old English . . . . . . . . . . . . . . . . . . . . . . . . . . . 14

$3.1 .2 \quad$ Middle English $\ldots \ldots \ldots \ldots \ldots$

$3.1 .3 \quad$ Modern British English $\ldots \ldots \ldots \ldots$

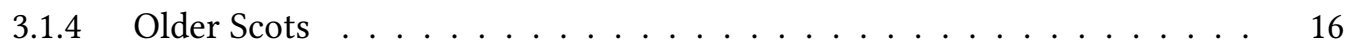

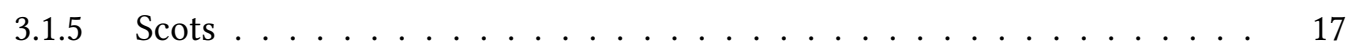

$3.1 .6 \quad$ Irish English . . . . . . . . . . . . . . . . . . . . . . . . . . 18

3.1 .7 Old Low German/Old Saxon . . . . . . . . . . . . . . . . . . . . . . . . 18

3.1 .8 Middle Low German . . . . . . . . . . . . . . . . . . . . . . . . . . . . . 19

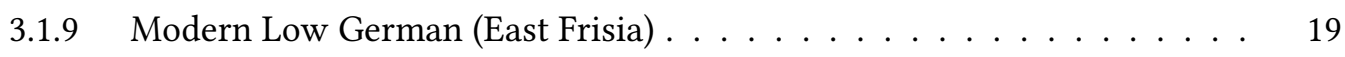


3.1 .10 Modern Low German Dithmarschen . . . . . . . . . . . . . . . . . . . . 20

3.1 .11 Old Frisian . . . . . . . . . . . . . . . . . . . . . . . 21

3.1 .12 Fering . . . . . . . . . . . . . . . . . . . . . . . . . . . . . . . . . . . . .

3.1 .13 Modern West Frisian . . . . . . . . . . . . . . . . . . . . . . . 22

3.1 .14 Old Dutch . . . . . . . . . . . . . . . . . . . . . . . . . . . . . . . . . . . . . . . . . . . .

3.1 .15 Middle Dutch . . . . . . . . . . . . . . . . . . . . . 23

3.1 .16 Modern Dutch . . . . . . . . . . . . . . . . . . . . . 24

3.1 .17 Old High German . . . . . . . . . . . . . . . . . . . . . . . . . . . . . . . . . . . . . . . . . . . . . . .

3.1 .18 Middle High German . . . . . . . . . . . . . . . . . . . . . . . . . . . . . . . . . . . . . . .

3.1.19 Modern High German . . . . . . . . . . . . . . . . . . . . . . . . . . . . . . . . . . . . . . .

3.2 North Germanic . . . . . . . . . . . . . . . . . . . . . . . . . . . . . . . . . 27

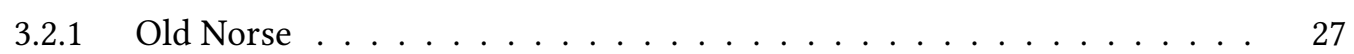

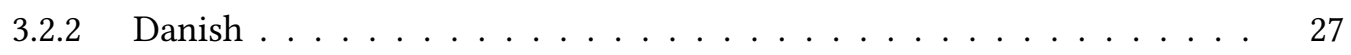

$3.2 .3 \quad$ Norwegian (Bokmål and Nynorsk) . . . . . . . . . . . . . . . . . . . . 28

3.2 .4 Icelandic . . . . . . . . . . . . . . . . . . . . . . . . . . . . . . . . . .

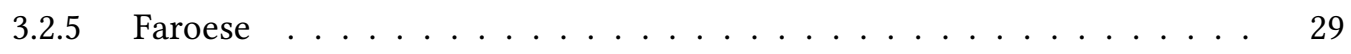

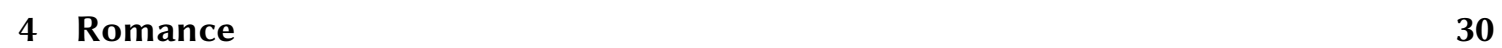

$4.1 \quad$ Old French (Francien) $\ldots$. . . . . . . . . . . . . . . . . . . . . . . . . . . . 30

4.2 Old French (Norman, Anglo-Norman) . . . . . . . . . . . . . . . . . . . . . . . . 31

4.3 Jersey-Norman/Jèrriais . . . . . . . . . . . . . . . . . . . . . . . . . . . . . . . . . . . . . . . . . .

4.4 Norman/Normand . . . . . . . . . . . . . . . . . . . . . . . . . . . . . . . . . . . . . .

4.5 Ancien Picard . . . . . . . . . . . . . . . . . . . . . . . . . 33

4.6 Picard . . . . . . . . . . . . . . . . . . . . . . . . 34

4.7 Modern Standard French . . . . . . . . . . . . . . . . . . . . 34 


\section{Variables}

positional dependency Is the position of the reflexive marker dependent on the position of the verb? I.e. is there a rule that the marker must be placed relative to the verb? This includes basic rules like 'the reflexive marker is the innermost marker left of the verbal root' or more complex ones like 'with regular inflected verbs, the marker is in slot 3 of the verbal template, but in slot 1 with infinitives.'

In Middle Welsh (1a), the position of the reflexive marker $y m$ - is determined by the position of the verb, whereas, e.g., the Icelandic reflexive pronoun can be positioned freely $(1 \mathrm{~b}-\mathrm{c}) \mathrm{f}^{1}$
a. na-ry-ym-wel-ssynt
NEG-PST-REFL-SEe-PLUP.3PL
'they had not see each other'
b. ég skammast mín
1SG.NOM be ashamed.PRS.SG 1SG.GEN
'I am ashamed'
c. Sér pvoði María fyrr i dag
REFL.3.DAT wash.PST.3sG M.NOM earlier today
'María washed earlier today'
(J. G. Jónsson 2011 109)

stress Can the reflexive marker establish its own stress domain? We have opted for splitting stress and phonological interaction into two values as stress domains tend to be larger than other domains of phonological and prosodic interaction (Bickel, Hildebrandt, and Schiering 2009 72) and this distinction helps capturing variation in our data.

The O-pronouns used in Old English to denote reflexivity (2a) establish their own stress domain, i.e. theyneed not attach to another stressed formant, while the medio-passive verbal endings of Old Norse (2b) always attach to a fully stressed verb.
a. hi hie pa up ahofon
3PL.NOM 3PL.ACC then up raise.PST.PL
'then, they raised themselves' $\quad(\mathrm{AO} 94.34)$
b. bjó-sk hann pá til hólmg̨ngu
prepare.PST-2/3sG.MP.PASs 3sG.M then to duel.gEN.SG
'he then prepared for the duel'
(Eg 235.21)

interaction Does the reflexive marker interact phonologically with surrounding linguistic items (i.e. vowel harmony, liaison, mutations etc.)? This includes the whole range of phonological integration like syllabification patterns, vowel harmony phenomena, liaison, etc. but excludes stress (s. above).

A case without interaction are the Standard British English X-self-reflexives (3a). The Omarkers used in Old Irish mutate following initial consonants and take part in syllabification processes operating left of the formant (3b).
(3)
a. He hit himself.
b. no-m·isligur
$\varnothing$-1SG.P·abase.PRS.1SG

\footnotetext{
${ }^{1}$ Abbreviations used in glosses:
} 
allomorphy Does the reflexive marker display phonologically, morphologically, syntactically or lexically conditioned allomorphy if all relevant features (i.e. number, person, case, TAM of the verb) remain the same?

The prime example of a construction with no allomorphy what so ever is the Low German Dialect of Dithmarschen that uses the marker sik in all positions and with all possible formants (4a). The Old Irish p-pronouns employed as reflexive markers alternate according to the element preceding them and to the sentence type (main clause/subordinate clause, positive/negative) (4b-c). Purely phonological alternations are considered under interaction.
a. Wir wüllt sik eerst mol waschen.
1PL.A want.PRS.PL REFL first wash.INF
'We want to wash ourselves first'
(Lindow 1998 158)
b. no-m·ísligur
$\varnothing-1 \mathrm{sG} . P \cdot a b a s e . P R s .1 \mathrm{SG}$
'I abase myself'
(Wb. 17d22)
c. ar-nda.cumcabat
for-3PL.P.raise.PRS.3PL
'in order that they may raise themselves' (MI. 46a12)

inflection Is the reflexive marker specified for a) person, b) number, and/or c) case?

positioning Where is the marker positioned with respect to the verbal root (PRE or POST)? The marker may be positioned to the left of the verbal root or to its right or, as in some cases, both. The reciprocal marker of Modern Breton for example is strictly preverbal (5a), while the medio-passive endings of Old Norse are strictly postverbal (5b). The P-pronouns of Old English may occur on both sides of the verb (5c-d).
a. me nõm zi'ven
1SG.A REFL defend.PRS
'I defend myself'
b. bjó-sk hann pá til hólmgongu
(Wmffre 1998: 28)
prepare.PST-2/3sg 3sG.M then to duel.GEN.SG
'he then prepared for the duel'
c. hi hie pa up ahofon
3PL.NOM 3PL.ACC then up raise.PST.PL
'then, they raised themselves' $\quad(\mathrm{AO}$ 94.34)
d. Pa æeteowode se deofol hine pam
then show.PST.3SG ART.NOM.SG devil.NOM.SG 3SG.M.ACC ART.DAT.SG
halgan were.
holy.DAT.SG man.DAT.SG
'Then the devil showed himself to the holy man.' (ÆCH2 11.206-207)

equivalence set Does the marker form an equivalence set with passive or reciprocal? I. e. is the reflexive marker also used to express passives or reciprocals? Both functional overlaps are widely attested in the languages of the world and are present in our sample (e.g. the Old Norse "medio-passive" is used to form reflexives, reciprocals, and anti-passives). Like with 
reflexive marking in general, we do not distinguish between "normal" or "unmarked" ways to express these two functions, but also include marginal strategies.

The Modern Standard French se construction can be used to encode all three functions (6a-c) while Middle Welsh X-hun(an) is reflexive only (6d).

(6) a. Il se lave.

3sG.M.A 3.REFL wash.PRS.3SG

'he washes'

b. Il ne se trouvait pas de linguiste pour traduire le 3SG.M.A NEG 3.REFL find.IPF.3SG NEG of linguist for translate.INF ART document.

document

'You couldn't find a linguist to translate the document.'

(Batchelor and Chebli-Saadi 2011: 321)

c. Alors nous nous battons?

so $1 \mathrm{PL} 1 \mathrm{PL}$ beat.PRs.1SG

'So, we're going to fight, aren't we?' (Guentchéva and Rivière 2007; 583)

d. o-ny-led-y du-hun

if-NEG-kill-NPST.2SG 2SG-INT

'unless you kill yourself' (GWV 10.24.35)

expandable Can the reflexive construction be expanded with an intensifier or a similar formant for stress, clarification or similar ends? For most languages in our sample this is identical to the reflexive-intensifier distinction variable of SAE, but we wanted this variable to have a broader scope in the event one of the languages without this distinction developed the ability to use an additional reflexive/intensifier (e.g. ${ }^{* *}$ I myself hurt myself). Compare Modern Standard German (7a) and Standard British English (7b).
a. Sie schlägt sich (selbst).
3SG.F.NOM hit.3SG.PRS REFL.3 INT
'she hits herself'
b. She hits herself $\left({ }^{*}\right.$ herself).

third person number syncretism Does the reflexive marker distinguish number values in the third person? With this variable, we try to capture a common variation in our data, e.g. zero differentiation with Modern High German sich (8a), full differentiation like in Modern Standard English (8b), or is there one marker that is used for singular and plural, while there is another one that encodes plural only like in Fering, where the singular P-pronoun can also be used in plural constructions (8c-d).
a. Sie
wäscht
'She washes. They wash.'
b. He sees himself. They see themselves.
c. Diartu sköömet ik me altu dol.
Dazu schäme ich mich allzu sehr
'I'm too ashamed to do that'

sich. Sie waschen

sich.

3SG.F.NOM wash.PRS.3SG 3.REFL 3PL wash.PRS.3PL 3.REFL

(Arfsten and Vanselow 2014 36) 
d. jo feel ham muar (...) tu Deenemark hentonjen

3PL.A feel.PRS REFL more to Denmark draw to.PPL

'they feel stronger drawn towards Denmark' (Drabek 2007 12.39)

\section{Insular Celtic}

\subsection{Goidelic}

\subsubsection{Old Irish}

Old Irish is the language spoken in Ireland, the Isle of Man and north-western Scotland between c. 700 and $900 \mathrm{CE}$ (Stifter 2010 55-56).

(9) no-m-ísligur

$\varnothing$-1sG.P-abase.PRs.1sG

'I abase myself' $\quad$ (Wb. 17d22)

It uses the referential identity of regular P-markers and A-markers to encode reflexivity. These P-markers occupy a fixed position in the left periphery of the verb (to the extent that semantically empty preverbal material like no- in ex. (9) is added to provide the respective slot) and are part of the verb's stress domain. They trigger so-called initial mutations (segment mutations of initial sounds of following phonological material).

The P-markers inflect for number and person (without number syncretism in the third person), but not for case. There are four sets of these markers, the appearence of which is determined by the item directly to its left. They cannot be used for the expression of reciprocals or passives. An additional marker féin is used to disambiguate reflexive from transitive use of third person markers or for emphasis (Irslinger 2014. 179-182; Thurneysen 1946: 255-269).

1. positional dependency: TRUE

2. phonological interaction:-STRESS, +INTERACTION

3. allomorphy: TRUE

4. inflection: +NUMBER, +PERSON, -CASE

5. position: + PRE, + POST

6. equivalence set with-RECIPROCAL, -PASSIVE

7. expandable: TRUE

8. syncretism: FALSE

\subsubsection{Middle Irish}

Middle Irish, the language spoken in Ireland, the Isle of Man, and most of Highland Scotland from c. 900 to $1250 \mathrm{CE}$, still uses the referential identity of regular P-markers and A-markers as described for Old Irish (s. 2.1.1. ex. (10b)), but has developed the additional possibility of using free personal pronouns instead of the bound P-markers (10a).

(10) a. in tan tuc-ais fén tú i-sin croich

when give-PRT.2SG INT 2SG in-ART cross

'when you gave yourself to the cross' 


\section{b. r-a-mbertaig}

PST-3SG.M.shake.PST.3SG

'he shook himself'

(O’Rahilly 1967, 98)

The free pronouns are generally positioned postverbally (as Middle Irish is a language with rather rigid verb initial syntax) but are positionally unbound. They do not interact phonologically with surrounding material and establish their own stress domain. They display some amount of allomorphy as there are special forms used with prepositions. They inflect for number and person (without third person number syncretism) and can't be used to express passives or reciprocals. Like the bound P-markers, they can be expanded by an intensifier féin (Irslinger 2014 179-181; Dottin 1913 223, 211-2; Stifter 2010 55-56).

1. positional dependency: вотн

2. phonological interaction: \pm STRESS, \pm INTERACTION

3. allomorphy: TRUE

4. inflection: +NUMBER, +PERSON, -CASE

5. position: $\pm \mathrm{PRE}, \pm \mathrm{POST}$

6. equivalence set with-RECIPROCAL, -PASSIVE

7. expandable: TRUE

8. syncretism: FALSE

\subsubsection{Modern Irish}

Modern Irish, spoken mainly in the west of Ireland [ $^{2}$ uses a combination of oblique personal pronouns (both direct (11a) and indirect (11b)) and $f(h)$ éin to express reflexives.
a. bháithinn-se
mé héin le
dinglis
drown.COND.1SG-EMPH.1SG 1SG REFL tickle.SG
'I'd drown myself laughing'
b. fuair mise balthadh bréan orm héin get.PST 1SG.EMPH smell.sG putrid on.1SG REFL
'I put a putrid smell on myself'
c. Níor bhain se éadach a bith dhi
NEG.PST PST.extract, take, leave 3sG.M clothes at all to.3sG.M
(Ó Curnáin 2007: 2, 1308)
'He did not take off any clothes'
(Ó Curnáin 2007: 2, 1309)

The construction is positioned right to the verb (as Modern Irish is a relatively strict verb initial language) and its placement is not dependent on that of the verb. It can establish its own stress domain, but does not interact with surrounding linguistic material. It displays some amount of allomorphy as there are special forms of the pronoun used with prepositions. The pronoun inflects for number and person (without third person number syncretism), but not for case; the forms can't be used to form reciprocals or passives. As the former intensifier $f(h)$ éin (s. sections 2.1.2 2.1.1 is now an inherent part of the construction - except for some of the rare instances where it

\footnotetext{
${ }^{2}$ The data presented here are based on the dialect of Iorras Aithneach (Ó Curnáin 2007) and the Standard language.
} 
can be omitted (11c) - and the whole construction is used as an intensifier, there is no way to expand the reflexive marker (Ó Murchú 2013 132-133; Stenson 2008 178-179; Ó Curnáin 2007. $2,1305-1312,3,1890)$.

1. positional dependency: FALSE

2. phonological interaction: +STRESS, -INTERACTION

3. allomorphy: TRUE

4. inflection: +NUMBER, +PERSON, -CASE

5. position: $-\mathrm{PRE},+\mathrm{POST}$

6. equivalence set with-RECIPROCAL, -PASSIVE

7. expandable: FALSE

8. syncretism: FALSE

\subsubsection{Scottish Gaelic}

Scottish Gaelic, the language spoken mainly in western Highland Scotland and the Hebrides, uses a combination of a personal pronoun and fhèin ${ }^{3}$ to express reflexivity.

chunna mi mi-fhèin

see.PST 1SG 1SG-self

'I saw myself'

(Lamb 2002 35)

The placement of PRON + fhèin is not dependent on the verb, but as Scottish Gaelic is a rather strict VSO-language, it is always found right of the verb. The construction can establish its own stress domain and does not interact phonologically with surrounding linguistic material. Prepositions trigger some allomorphy in the pronoun. It inflects for number and person (without third person number syncretism), but not for case; it can't be used to form reciprocals or passives. As PRON + fhein itself is the intensifier that would be used with a construction like this, there no way of expanding the construction (Lamb 2002 35-36; Calder $1980 \quad 163-164$ ).

1. positional dependency: FALSE

2. phonological interaction: +STRESS, -INTERACTION

3. allomorphy: TRUE

4. inflection: +NUMBER, +PERSON, -CASE

5. position: $-\mathrm{PRE},+\mathrm{POST}$

6. equivalence set with-RECIPROCAL, -PASSIVE

7. expandable: FALSE

8. syncretism: FALSE

\footnotetext{
${ }^{3}$ In some dialects, there is an additional first person variant fhin.
} 


\subsubsection{Late Manx}

Late Manx, a Goidelic language spoken on the Isle of Man between c. 1800 and 1974 CE, when its last native speaker died, uses a combination of personal pronoun and hene to denote reflexivity.

$$
\begin{aligned}
& \text { v'eh laccal ... ceau eh hene ayns yn keayn } \\
& \text { be.PST.3sG.M want.vn throw.vn 3sG.M.REFL in ART.SG sea } \\
& \text { 'he wanted to throw himself into the sea' } \\
& \text { (Broderick 1984 1, 283) }
\end{aligned}
$$

The position of personal pronoun + hene is not dependent on the verb, but Late Manx being a verb-initial language, the combination cannot occur preverbally. It establishes its own stress domain and does not interact phonologically with surrounding phonological material. There is some allomorphy triggered by prepositions. It inflects for number and person (without third person number syncretism), but not for case. It does not form reciprocals or passives, and cannot be expanded by any means (Phillips 2004 20-21; Broderick 1984: 1, 54-57, 64).

1. positional dependency: FALSE

2. phonological interaction: +STRESS, -INTERACTION

3. allomorphy: TRUE

4. inflection: +NUMBER, +PERSON, -CASE

5. position: -PRE, +POST

6. equivalence set with -RECIPROCAL, -PASSIVE

7. expandable: FALSE

8. syncretism: FALSE

\subsection{Brittonic}

\subsubsection{Middle Welsh}

Middle Welsh, the language spoken in Wales and adjacent English territories between c. 1150 and $1450 \mathrm{CE}$. It uses a preverbal reflexive marker $y m-(14 \mathrm{a}-\mathrm{b})$ or the combination of a possessive pronoun and a former intensifier hun(an) (14c).
a. $y d-y m$-dengys
AFF-REFL-show.PRS.3SG
'it reveals itself'
b. nac-ym-hoff-a
vyth $d y$-hun
(Peniarth 14, 63; RhGL13)
NEG-REFL-praise-IMP.2SG ever 2SG-INT
'do not ever praise thyself'
(CD 29.37)
c. o-ny-led-y du-hun
if-NEG-kill-NPST.2SG 2SG-INT
'unless you kill yourself'
(GWV 10.24.35)
d. na-ry-ym-wel-ssynt
NEG-PST-REFL-See-PLUP.3PL
'they had not see each other'
(RhGL13 Llanstephan 1, 147) 
The reflexive marker $y m$ - occupies a fixed position in the left periphery of the verb and is part of its stress domain. It causes a segment mutation on the left edge of the verb and takes part in vowel elision processes with linguistic material to its left. There is no allomorphy and the marker does not inflect for person, number, or case; it is also used to express reciprocity (14d), but not to form passives. It can be expanded by a combination of a possessive pronoun and the intensifier hun(an).

The position of the combination of possessive pronoun and hun(an) is not determined by the position of the verb, but the marker only occurs postverbally. It does not interact with its linguistic surroundings and establishes its own stress domain. The possessive pronoun inflects for person and number (although not in the third person) and the whole construction takes left edge case markers (usually dubbed prepositions but lacking the usual prepositional properties of governing case and the possibility for stranding). They can't be used for the formation of passives or reciprocals and they cannot be expanded in any way (Irslinger 2014 189-190; Evans 1964 §98; Schumacher 2011 143-144).

1. positional dependency: вотн

2. phonological interaction: \pm STRESS, \pm INTERACTION

3. allomorphy: вотн

4. inflection: \pm NUMBER, \pm PERSON, \pm CASE

5. position: $\pm \mathrm{PRE}, \pm \mathrm{POST}$

6. equivalence set with \pm RECIPROCAL, - PASSIVE

7. expandable: вотн

8. syncretism: TRUE

\subsubsection{Northern Welsh}

Northern Welsh, the modern dialects of Welsh spoken in the northern parts of Wales, uses a combination of possessive pronoun and the reflexive hun to express reflexivity. There are however some lexicalized remnants of the Middle Welsh construction with ym- (section 2.2.1).
a. hitio-i hun
hit.vN-POSS.3SG REFL
'hitting him/herself'
b. hitio-u hunan/hunin
hit.VN-3PL REFL.PL
'hitting themselves'
(Iwan Rees, p.c.)
(Iwan Rees, p.c.)

The position of possessive + hun or, in the plural, hunan/hunin is not determined by the verb, it establishes its own stress domain, but the possessive marker takes part in usual vowel elision processes if the preceding element ends in a vowel. As Northern Welsh is verb initial, poss + hun is positioned postverbally. After certain prepositions, some of the possessive markers display allomorphy. The possessive marker inflects for person and number (without third person number syncretism), but not for case (the case markers of Middle Welsh recently developed prepositional properties); it can't be used to express reciprocals or passives. As Poss + hun is used as an intensifier, it is not possible to expand the construction any further (G. King 2003 96-98; Irslinger 2014 189-190; Thomas 1996 267-269; Iwan Rees, p.c.). 
1. positional dependency: FALSE

2. phonological interaction: +STRESS, +INTERACTION

3. allomorphy: TRUE (changes after preps ending in a vowel)

4. inflection: +NUMBER, +PERSON, -CASE

5. position: -PRE, +POST

6. equivalence set with-RECIPROCAL, -PASSIVE

7. expandable: FALSE

8. syncretism: FALSE

\subsubsection{Southern Welsh}

Southern Welsh, the modern dialects of Welsh spoken in the southern parts of Wales, uses a combination of possessive pronoun and a reflexive hunan to express reflexivity. There are however some lexicalized remnants of the Middle Welsh construction with ym- (section 2.2.1).
a. bwrw-i hunan
hit.vN-3SG REFL.SG
'hitting him/herself'
b. bwrw-u hunen
hit.VN-3PL REFL.PL
'hitting themselves'
(Iwan Rees, p.c.)
(Iwan Rees, p.c.)

The position of possessive + hunan or, in the plural, hunen is not determined by the verb, it establishes its own stress domain, but the possessive marker takes part in usual vowel elision processes if the preceding element ends in a vowel. As Northern Welsh is verb initial, poss + hunan is positioned postverbally. After certain prepositions, some of the possessive markers display allomorphy. The possessive marker inflects for person and number (without third person number syncretism), but not for case (the case markers of Middle Welsh recently developed prepositional properties, cf. Borsley, Tallerman, and Willis 2007 116); it can't be used to express reciprocals or passives. As Poss + hunan is used as an intensifier, it is not possible to expand the construction any further (G. King 2003 96-98; Irslinger 2014 189-190; Thomas 1996 267-269; Iwan Rees, p.c.).

1. positional dependency: FALSE

2. phonological interaction: +STRESS, +INTERACTION

3. allomorphy: TRUE (changes after preps ending in a vowel)

4. inflection: +NUMBER, +PERSON, -CASE

5. position: $-\mathrm{PRE},+\mathrm{POST}$

6. equivalence set with -RECIPROCAL, -PASSIVE

7. expandable: FALSE

8. syncretism: FALSE 


\subsubsection{Middle Breton}

Middle Breton, the language spoken in most of Brittany between c. 1100 and $1700 \mathrm{CE}$, uses a cliticised particle em- cognate to Welsh ym- (section 2.2.1) and Cornish om-/em-/ym- (section 2.2.6 to express reflexivity. It is usually preceded by an P-marker coreferential with the A-marker on the verb as indicated in (17).

$$
\begin{aligned}
& \begin{array}{lll}
\text { a. an } \text { diaoul }_{i}(\ldots) \text { en }_{i} \text {-em-lacas } & \text { (..) e-nn ydol }
\end{array} \\
& \text { ART devil 3SG.P-REFL-put.3sg.Pst in-ART idol } \\
& \text { 'the devil put himself in the idol' }
\end{aligned}
$$

Like the P-marker preceding it, $\mathrm{em}$ - has a fixed position in the left periphery of the verb and is part of its stress domain. It causes a segment mutation on the initial sound of the following verbal root and takes part in preverbal vowel elision processes. em- is the sole form, there is no allomorphy. The P-marker adds information for person and number (without number syncretism in third person forms), but not for case; it is not used to form passives, and, in contrast to Modern Breton (section 2.2.5), it can't form reciprocals. The reflexive can be expanded with poss + hun(an) (Hemon 1984 271-273; Irslinger 2014 187; Roux 1957 254-255).

1. positional dependency: TRUE

2. phonological interaction:-STRESS, +INTERACTION (mutation, vowel elision)

3. allomorphy: FALSE

4. inflection: +NUMBER, +PERSON, -CASE

5. position: +PRE, -POST

6. equivalence set with -RECIPROCAL, -PASSIVE

7. expandable: TRUE

8. syncretism: FALSE

\subsubsection{Central Breton}

Central Breton, the sub-dialect of Cornouaillais spoken close to the town of Carhaix-Plouguer in lower Brittany, uses the reflexive particle nõm to denote reflexivity.

$$
\begin{aligned}
& \text { me nõm ziven } \\
& \text { 1sG.A REFL defend.PRS } \\
& \text { 'I defend myself' }
\end{aligned}
$$$$
\text { (Wmffre 1998: 28) }
$$

The particle is placed in a fixed position directly left of the verb and is part of the verb's stress domain. It phonologically interacts with the following verbal root by causing a segment mutation of its leftmost consonant, e.g. /d/ in diven 'defend' becomes /z/ in (18). nõm is the only marker, i.e. there is no allomorphy, and it does not inflect for number, person, or case. It can be used to denote reciprocals but not passives. An element poss $+h \tilde{x} n$ can be used to expand the reflexive (Wmffre 1998 27-28; Timm 1987, 287-288)

1. positional dependency: TRUE

2. phonological interaction:-STRESS, +INTERACTION 
3. allomorphy: FALSE

4. inflection:-NUMBER, -PERSON, -CASE

5. position: +PRE, -POST

6. equivalence set with +RECIPROCAL, -PASSIVE

7. expandable: TRUE

8. syncretism: TRUE

\subsubsection{Middle Cornish}

Middle Cornish, the language spoken in Cornwall between c. 1100 and $1600 \mathrm{CE}$, makes use of an affix om-/ym-/em- cognate to Middle Welsh ym- (section 2.2.1) and Middle Breton em- (section 2.2.4.

$$
\begin{aligned}
& \text { a. Guet-yogh om-previ manly } \\
& \text { take care-IMP.2PL REFL-prove.vN manly } \\
& \text { 'take care to prove yourself manly' } \\
& \text { b. rag om-sawya ow-honyn } \\
& \text { to REFL-save.vN 1SG-self } \\
& \text { 'to save myself' }
\end{aligned}
$$$$
\text { (BM 1194) }
$$$$
\text { (CW] 2374-5) }
$$

The reflexive marker is positioned directly left of the verbal root and is part of its stress domain. It phonologically interacts with the initial consonant of the following verbal root, inducing a segment mutation. The variation seen in the vowel is phonological and, at least in part, orthographical and cannot be interpreted as a case of allomorphy. The marker does not inflect for number, person, or case, and can form reciprocals but not passives. An intensifier honen, preceded by a possessive marker, can be added to expand the construction (Williams 2011: 325; Irslinger 2014: 188-189; Toorians 2014. 5.3, 5.25, 5 n. 12).

1. positional dependency: TRUE

2. phonological interaction:-STRESS, +INTERACTION

3. allomorphy: FALSE

4. inflection:-NUMBER, -PERSON, -CASE

5. position: +PRE, - POST

6. equivalence set with + RECIPROCAL, - PASSIVE

7. expandable: TRUE

8. syncretism: TRUE 


\subsubsection{Late Cornish}

Late Cornish, spoken in Cornwall between c. 1600 and its death some time in the late 18th or early 19th century CE, uses a reflexive honen preceded by a dependent pronominal element.

(20) hedha go-honnen

stretch.VN 3PL-REFL

'stretching themselves'

(Wmffre 1999; 33)

The reflexive marker poss + honen is positionally and phonologically unbound (the comparatively small corpus does not contain any examples of a preverbal use of the marker, but this cannot be taken as evidence against the possibilty of preverbal use), i.e. it can be positioned freely, establishes its own stress domain and does not interact phonologically with surrounding linguistic material. The form of the possessive marker changes after prepositions, and the marker can thus be said to display allomorphy. It does inflect for person and number (without third person number syncretism); it does not inflect for case. It can't be used to form reciprocals or passives. There is no intensifier or similar formant that can be added to expand the construction (Wmffre 1999. 33-34; Williams 2011 325; Toorians 2014 5.3, 5.25, 5 n. 12).

1. positional dependency: FALSE

2. phonological interaction: +STRESS, -INTERACTION

3. allomorphy: TRUE

4. inflection: +NUMBER, +PERSON, -CASE

5. position: ?PRE, + POST

6. equivalence set with -RECIPROCAL, -PASSIVE

7. expandable: FALSE

8. syncretism: FALSE

\section{Germanic}

\subsection{West Germanic}

\subsubsection{Old English}

Old English, spoken in an area roughly identical with present day England between c. 700 and $1100 \mathrm{CE}$, uses the referential identity of P-pronouns with the A-argument encoded on the verb and in overt pronouns to express reflexivity.
a. hi hie pa upahofon
3PL.NOM 3PL.ACC then up raise.PST.PL 'then, they raised themselves'
b. Pa æteowode se deofol
deofol hine pam halgan
then show.PST.3sg ART.NOM.SG devil.NOM.SG 3sG.M.ACC ART.DAT.SG holy.DAT.SG
were.
man.DAT.SG

'Then the devil showed himself to the holy man.' (ÆCH2 11.206-207) 
The P-pronoun is positioned freely in the sentence and phonologically unbound - it does establish its own stress domain and does not interact phonologically with surrounding material. The pronoun inflects for person, number, and case (without number syncretism in the third person) in a single paradigm without any allomorphy. As in more or less all Old Germanic varieties, the pronouns can also be used to encode reciprocals, but not passives. An intensifier self can be added to expand the construction and disambiguate between reflexive and non reflexive use of third person pronouns (Irslinger 2014: 178; Nedjalkov 2007 158; Gelderen 2000 27-62).

1. positional dependency: FALSE

2. phonological interaction: +STRESS, -INTERACTION

3. allomorphy: FALSE

4. inflection: +NUMBER, +PERSON, +CASE

5. position: + PRE, + POST

6. equivalence set with +RECIPROCAL, -PASSIVE

7. expandable: TRUE

8. syncretism: FALSE

\subsubsection{Middle English}

Middle English, the language spoken in an area roughly equivalent to present day England and in some areas in southern Wales between c. 1150 and 1500, like its predecessor Old English (section 3.1.1 uses the referential identity of P-pronouns and A-markers on the verb and A-pronouns to encode reflexivity.
a. And to hym I haf me tone
and to him 1sG.NOM have.PRS.1sG 1sG.ACC take.PPL
'and to him I have committed myself'
b. Bot zet he sayde in hymself
but yet 3sG.M say.PST in himself
'but still he said to himself'
(SGGK 1198)

The P-pronoun is positioned freely in the sentence and phonologically unbound - it does establish its own stress domain and does not interact phonologically with surrounding material. The pronoun inflects for person, number, and case (without number syncretism in the third person) in a single paradigm without any allomorphy. As in more or less all Old and medieval Germanic varieties, the pronouns can also be used to encode reciprocals, but not passives. An intensifier self can be added to expand the construction, which is much more frequent than in Old English (Gelderen 2000 119).

1. positional dependency: FALSE

2. phonological interaction: +STRESS, -INTERACTION

3. allomorphy: FALSE

4. inflection: +NUMBER, +PERSON, +CASE 
5. position: + PRE, + POST

6. equivalence set with +RECIPROCAL, -PASSIVE

7. expandable: TRUE

8. syncretism: FALSE

\subsubsection{Modern British English}

Modern British English uses the reflexive pronouns and intensifiers myself, yourself, etc. to express reflexivity, but, these reflexives are ousted in middle situations by labile verbs.
a. I gave myself a present.
b. I gave a present to myself.

Other than being prohibited from occupying the preverbal position which is reserved for s- and A-pronouns, the reflexive pronoun's position is not determined by the verb. It establishes its own stress domain and does not interact phonologically with surrounding material. It inflects for number and person (without third person number syncretism), but not for case, and does not show any signs of allomorphy. It does not form passives or reciprocals and cannot be expanded (Mondorf 2012 846-851; Huddlestone and Pullum 2005 105-106).

1. positional dependency: FALSE

2. phonological interaction: +STRESS, -INTERACTION

3. allomorphy: FALSE

4. inflection: +NUMBER, +PERSON, -CASE

5. position: $-\mathrm{PRE},+\mathrm{POST}$

6. equivalence set with-RECIPROCAL, -PASSIVE

7. expandable: FALSE

8. syncretism: FALSE

\subsubsection{Older Scots}

Older Scots, the language descending from northern Anglian Old English Dialects spoken in the Scottish Lowlands between c. 1150 and 1650 CE, uses the referential identity of P-pronouns with the A-argument expressed by verbal endings and A-pronouns to express reflexivity.
a. magdalene, pat fyrst hyre
gaf til al delyt
M. $\quad$ REL first 3SG.F.OBL.REFL give.PST to all delight
'Magdalene, who first gave herself to all delight' (Barbour 1896 1, 257, 44-45)
b. He mycht nocht...bryng his handis til his
3SG.M.NOM be able.PST NEG bring.INF POSS.3SG.M hand.ACC.PL to POsS.3sG.M
face to fed hyme-self
face to feed 3sG.M.OBL.REFL-INT
'He could not bring his hands to his face to feed himself.'

(Barbour 1896: 2, 336, 1107-1109) 
The P-pronoun is neither positionally nor phonologically bound, i.e. its position is not determined by the verb, it does not interact phonologically with surrounding material and it establishes its own stress domain. It inflects for person, number, and case without third person number syncretism in a single paradigm, i.e. not displaying any allomorphy. Like in all older and medieval Germanic varieties, the pronouns can be used to form reciprocals but not passives. They can be expanded by the addition of the intensifier -self (A. King 1997: 170).

1. positional dependency: FALSE

2. phonological interaction: +STRESS, -INTERACTION

3. allomorphy: FALSE

4. inflection: +NUMBER, +PERSON, +CASE

5. position: + PRE, + POST

6. equivalence set with + RECIPROCAL, - PASSIVE

7. expandable: TRUE

8. syncretism: FALSE

\subsubsection{Scots}

Scots, the modern West Germanic language spoken in Lowland Scotland, on Orkney and Shetland, and in northern Ireland, uses reflexive pronouns formed by combining a originally possessive or dative pronoun and the reflexive element sel(s) to encode reflexivity.

Weel, it-ll no mend it-sel.

well 3SG.N-FUt NEG mend 3sG.N-REFL

'Well, it won't mend itself.'

(Eagle 2016: 100)

The reflexive pronouns are positionally free but can only occur postverbally. They establish their own stress domain and do not interact phonologically with any surrounding linguistic material. There is no allomorphy. The form inflects for person and number (maintaining the number distinction in third person forms), but not for case. The forms cannot be used to encode reciprocity or passives, and the form cannot be expanded by any means (Eagle 2016: 100-101; Beal 1997. 344-348).

1. positional dependency: FALSE

2. phonological interaction: +STRESS, -INTERACTION

3. allomorphy: FALSE

4. inflection: +NUMBER, +PERSON, -CASE

5. position: $-\mathrm{PRE},+\mathrm{POST}$

6. equivalence set with-RECIPROCAL, -PASSIVE

7. expandable: FALSE

8. syncretism: FALSE 


\subsubsection{Irish English}

Irish English uses the same pronouns as does Standard English with slight phonological and in some cases morphological alternations in the pronominal stem used to form the reflexives.

They carry theirselves decently.

(Hickey 2007, 244)

The position of the reflexive is not dependent on the position of the verb, but it occurs always postverbally. They canestablish their own stress domain and do not interact phonologically with their surroundings. As the stem of the pronominal part of the reflexive varies in the same form (themselves $\sim$ theirselves), the reflexives show allomorphy. They inflect for person and number (keeping the number distinction in the third person), but not for case. They cannot be used to form reciprocals or passives, and cannot be expanded by any form either (Hickey 2007 243-244; Amador-Moreno 2010 34-36).

1. positional dependency: FALSE

2. phonological interaction: +STRESS, -INTERACTION

3. allomorphy: TRUE

4. inflection: +NUMBER, +PERSON, -CASE

5. position: $-\mathrm{PRE},+\mathrm{POST}$

6. equivalence set with -RECIPROCAL, -PASSIVE

7. expandable: FALSE

8. syncretism: FALSE

\subsubsection{Old Low German/Old Saxon}

Old Low German or Old Saxon, the West-Germanic language spoken in northern Germany between c. 700 and $1150 \mathrm{CE}$, uses accusative and pronouns to denote reflexivity.

$$
\begin{aligned}
& \mathrm{Nu} \text { maht thu thi an thînan uuilleon ford } \\
& \text { when do.PRs.2sG 2sG.NOM 2sG.ACC in POss.2SG.ACC.SG will.ACC.SG away } \\
& \text { 'When you go away in your own will' }
\end{aligned}
$$

The pronouns are free in their positioning and can stand on either side of the verb. They do not interact with their surroundings and establish their own stress domain. There seems to be no allomorphy. The forms inflect for person, number, and case, number always being distinguished in the third person forms. Like in all older and medieval Germanic varieties, the pronouns can be used to encode reciprocals but not passives. The form self can be added to expand the construction (Gallée 1993 237-238, 241).

1. positional dependency: FALSE

2. phonological interaction: +STRESS, -INTERACTION

3. allomorphy: FALSE

4. inflection: +NUMBER, +PERSON, +CASE 
5. position: + PRE, + POST

6. equivalence set with +RECIPROCAL, -PASSIVE

7. expandable: TRUE

8. syncretism: FALSE

\subsubsection{Middle Low German}

Middle Low German, the West Germanic language spoken in northern Germany between c.1200 and $1550 \mathrm{CE}$, uses oblique personal pronouns in the first and second persons and a reflexive pronoun in the third person.

$$
\begin{aligned}
& \text { dat se sik des untsculdegheden. } \\
& \text { that 3PL.NOM REFL DEM.GEN.SG.N free of guilt.PRs.3PL } \\
& \text { 'that they rid themselves of this guilt' } \\
& \text { (Ebel 1968 II } 1 \text { §23) }
\end{aligned}
$$

The pronouns are positionally free and can occur on either side of the verb. They can establish their own stress domain and do not interact phonologically with the verb. There is no allomorphy. They inflect for person, number, and case, with the pronoun of the third person sik not distinguishing number. As in more or less all older and medieval Germanic varieties, the pronouns can be used to encode reciprocity, but not passives. An intensifier self/silf/sölf/sülf can be added to expand the construction (Lasch 1914, 213-217, 219).

1. positional dependency: FALSE

2. phonological interaction: +STRESS, -INTERACTION

3. allomorphy: FALSE

4. inflection: +NUMBER, +PERSON, +CASE

5. position: +PRE, + POST

6. equivalence set with + RECIPROCAL, -PASSIVE

7. expandable: TRUE

8. syncretism: TRUE

\subsubsection{Modern Low German (East Frisia)}

In the East Frisian Dialect of Modern Low German spoken in north-western Germany, the oblique pronouns of the first and second persons and a special number indifferent third person reflexive pronoun is used to denote reflexivity.
a. Vadder rösper
sük.
father clear one's throat.PRS REFL
'father clears his throat'

b. daar hett

he

sük sülvst an hulpen

(Lindow 1998 157)

there have.PRS.3SG 3SG.M.NOM REFL.3 INT at help.PTCP

'That's his own fault.'

(Brückmann n.d.: s.v. sülvst) 
c. Dåu musn däi zük eerst tuutn un drükn.

then must.PST.PL DEM REC first kiss.INF and hug.INF

'First they had to kiss and hug.'

(Matras and Reershemius 2003 26)

The pronoun is not positionally dependent on the verb and is always occurring right of finite forms and left of infinitives. It does form its own stress domain and does not phonologically interact with its surroundings. There is no allomorphy. The forms inflect for number, person, and case, not distinguishing number in the third person. They can be used to form reciprocals (29c), but not passives. An intensifier like form sülv-can be added to expand the construction (29b) (Lindow 1998 63, 69, 154-158, 276; Matras and Reershemius 2003. 22-26).

1. positional dependency: FALSE

2. phonological interaction: +STRESS, -INTERACTION

3. allomorphy: FALSE

4. inflection: +NUMBER, +PERSON, +CASE

5. position: + PRE, + POST

6. equivalence set with + RECIPROCAL, -PASSIVE

7. expandable: TRUE

8. syncretism: TRUE

\subsubsection{Modern Low German Dithmarschen}

The Modern Low German dialect spoken in the district of Dithmarschen in northern Germany uses an invariate reflexive marker sik to express reflexivity.

(30) Wir wüllt sik eerst mol waschen.

1PL.A want.PRS.PL REFL first wash.INF

'We want to wash ourselves first' (Lindow 1998 158)

The behaviour of $s i k$ is basically the same as in the dialect of East Frisia described above (section 3.1.9) with the difference that invariate $s i k$ is used for all persons and numbers (Lindow 1998: 63, $69,154-158,276)$.

1. positional dependency: FALSE

2. phonological interaction: +STRESS, -INTERACTION

3. allomorphy: FALSE

4. inflection:-NUMBER, -PERSON, -CASE

5. position: + PRE, + POST

6. equivalence set with + RECIPROCAL, -PASSIVE

7. expandable: TRUE

8. syncretism: TRUE 


\subsubsection{Old Frisian}

Old Frisian, a West Germanic language spoken in the coastel areas of present-day nort-western Germany and the northern Netherlands between c. 1200 and $1450 \mathrm{CE}$, used object pronouns to encode reflexivity.

$$
\begin{aligned}
& \text { thett-er hine selwa ne muge } \\
& \text { that-3SG.M.NOM 3sG.M.ACC INT NEG be able.SUBJ.PRS NEG take care.INF } \\
& \text { 'that he can't take care of himself' } \\
& \text { (Buma and Ebel 1965 §88) }
\end{aligned}
$$

The oblique personal pronouns are positionally free and can occur on either side of the verb. There is an allomorphy between cliticised (usually attaching to verbs or other pronouns, e.g. hia-ne 3PL.NOM-3SG.M.ACC) and free forms, the former not being able to establish their own stress domain and phonologically interacting with their surroundings. They inflect for number, person, and case, number being distinguished in third person. They can encode reciprocity, but not reflexivity. An element selw-/self-can be added to expand the construction (Markey 1981 131-135; Bremmer 2009 56).

1. positional dependency: FALSE

2. phonological interaction: \pm STRESS, \pm INTERACTION

3. allomorphy: TRUE

4. inflection: +NUMBER, +PERSON, +CASE

5. position: $+\mathrm{PRE},+\mathrm{POST}$

6. equivalence set with +RECIPROCAL, -PASSIVE

7. expandable: TRUE

8. syncretism: FALSE

\subsubsection{Fering}

The modern North Frisian Dialect of the Island Föhr uses the oblique/object-pronouns to express reflexivity (32a), but in the third person, a form $s i k$ borrowed from Low German is sometimes used as well.

(32) a. Diartu sköömet ik me altu dol.

Dazu schäme ich mich allzu sehr 'I'm too ashamed to do that'

b. uun a busemhaa jo sik duad-sweet in ART stable have.PRS 3PL.A REFL dead-sweat.PPL 'They sweated like hell in the stables.'

(Drabek 2007: 13.71)

c. jo feel ham muar (...) tu Deenemark hentonjen 3PL.A feel.PRS REFL more to Denmark draw to.PPL 'they feel stronger drawn towards Denmark' (Drabek 2007 12.39)

d. man dan sprääg hi ham salew weder mud tu but then say.PST 3SG.M.A 3SG.M.P INT again courage to 'but then he gave himself courage'

(Arfsten and Vanselow 2014 33) 
The pronouns are not positionally bound to the verb and can occur postverbally. Whether they can occur before the verb cannot be inferred from the literature. They can establish their own stress domain but are often cliticised to the preceding element (usually verbs or other pronouns) in which case they do not bear stress and phonologically interact with the element they are cliticised to. There is no allomorphy. The marker usually inflects for person, number, and case, except for the Low German loan sik and the third person form han which is used for both singular and plural in the speech of younger speakers if used reflexively. It is not used to form passives or reciprocals. The pronouns can be expanded by adding salew 'self' (Walker and Wilts 2001 294-295; Århammar 2001 344; Schmidt-Petersen and Craigie 1928: 13; Drabek 2007 49-52).

1. positional dependency: FALSE

2. phonological interaction: +STRESS, +INTERACTION

3. allomorphy: FALSE

4. inflection: +NUMBER, +PERSON, +CASE

5. position: ?PRE, + POST

6. equivalence set with-RECIPROCAL, -PASSIVE

7. expandable: TRUE

8. syncretism: ВОтн

\subsubsection{Modern West Frisian}

Modern West Frisian, the modern Frisian language spoken mainly in the north-west of the Netherlands, uses object personal pronouns to express reflexivity.
a. hja skamje har
3PL.A be ashamed.PRS.3PL 3PL.P 'they are ashamed'
b. heit skeart him-sels
father.A shave.PRs.3sg 3sG.M-self
'father shaves himself' (Tiersma 1985 66)
(Hoekstra 2001, 90)

The object pronouns are free in position and can occur on either side of the verb. They can establish their own stress domain, but are often cliticised to the verb or other preceding pronouns in which case they phonologically interact with the entity they are cliticised to. There is no allomorphy. They inflect for person, number, and case (differentiating third number in third person forms); they can't be used to express reciprocity or passives. The forms can be expanded by adding sels 'self' (Hoekstra 2001. 90; Tiersma 1999. 55-6627; Popkema 2013 86-91).

1. positional dependency: FALSE

2. phonological interaction: +STRESS, +INTERACTION

3. allomorphy: FALSE

4. inflection: +NUMBER, +PERSON, +CASE

5. position: + + PRE, + POST 
6. equivalence set with-RECIPROCAL, -PASSIVE

7. expandable: TRUE

8. syncretism: FALSE

\subsubsection{Old Dutch}

Old Dutch (or Old Low Franconian), a West Germanic Language spoken in the present-day Netherlands and northern Belgium between c. 650 and $1150 \mathrm{CE}$, uses oblique personal pronouns to encode reflexivity; in the third person, a loan from High German sig sporadically occurs.

$$
\begin{aligned}
& \text { thu irbulgi thi } \\
& \text { 2sG.NOM get angry.PST.2SG 2SG.ACC } \\
& \text { 'you got angry' }
\end{aligned}
$$$$
\text { (Quak 1992 102) }
$$

The pronouns are not positionally bound and can occur on either side of the verb. They can establish their own stress domain and the yphonologically interact with their surroundings. There is no allomorphy. The pronouns inflect for person, number, and case, keeping the number distinction in the third person, while sig is insensitive towards number. They can be used to form reciprocals but not passives. It cannot be inferred from teh literature, whether the constructions can be expanded in any way (Quak 1992 100-102).

1. positional dependency: FALSE

2. phonological interaction: +STRESS, +INTERACTION

3. allomorphy: FALSE

4. inflection: +NUMBER, +PERSON, +CASE

5. position: +PRE, + POST

6. equivalence set with +RECIPROCAL, -PASSIVE

7. expandable: ?

8. syncretism: FALSE

\subsubsection{Middle Dutch}

Middle Dutch, a West Germanic langauge spoken in the area of present day Netherlands and northern Belgium between c. 1150 and $1500 \mathrm{CE}$, uses the oblique pronouns as reflexives for all numbers and persons; the High German loan s/zich sporadically occurs in the third person.
a. Hie cleedde hem
3SG.M.A dress.PST 3sG.M.P
'He dressed.'
b. Sij vreysden sich sonder mate
3PL.A be afraid.PST REFL without limit
'They were extremely afraid.'
(Kerckevoorde 1993: 80)
(Kerckevoorde 1993: 80) 
The pronouns and s/zich are not positionally dependent on the verb, but it is not clear from the literature whether they can occur preverbally. They can establish their own stress domain and do not interact with their phonological surroundings. There is no allomorphy, The pronouns inflect for number, person, and case, distinguishing number in the third person, while third person s/zich is not specified for number. They cannot be used as reciprocals or passives. An intensifier selven can be added to expand the form (Franck 1910 177-178; Kerckevoorde 1993: 79-80; Kerckvoorde 1994 95-99).

1. positional dependency: FALSE

2. phonological interaction: +STRESS, -INTERACTION

3. allomorphy: FALSE

4. inflection: +NUMBER, +PERSON, +CASE

5. position: ?PRE, + POST

6. equivalence set with-RECIPROCAL, -PASSIVE

7. expandable: TRUE

8. syncretism: вотн

\subsubsection{Modern Dutch}

In Modern Dutch, reflexivity is expressed by P-pronouns in first and second persons and by a reflexive zich in the third person.

(36) u heeft zich gewassen

2 PST.3SG REFL wash.PPL 'you have washed'

(Donaldson 2017 258)

The pronouns are not positionally dependent on the verb. They usually occur after finite forms and before infinitives. There are stressed and unstressed forms which are in an allomorphic relationship to each other. Some of the unstressed forms can be cliticised to the verb in which case they are syllabified with the verb. They inflect for person, number, and case, with the number indifferent form zich in the third person. They cannot form reciprocals or passives. An intensifier -zelf can be added to expand the construction, mainly for emphasis (Donaldson 2017 66-80, 257-264; Shetter 1993: 67-69).

1. positional dependency: FALSE

2. phonological interaction: \pm STRESS, \pm INTERACTION

3. allomorphy: TRUE

4. inflection: +NUMBER, +PERSON, +CASE

5. position: + PRE, + POST

6. equivalence set with-RECIPROCAL, -PASSIVE

7. expandable: TRUE

8. syncretism: TRUE 


\subsubsection{Old High German}

Old High German, a West Germanic language spoken in present day southern Germany, Switzerland and western Austria between c. 750 and $1050 \mathrm{CE}$, employs a special reflexive pronoun $\mathrm{sin} / \mathrm{sih}$, which is not specified for gender, for the genitive singular and accusative cases of the third person, oblique personal pronouns for all other cases and persons.
a. Târ erslûog síh sélben cato.
there kill.PST.3Sg REFL INT Cato
'There Cato killed himself.' (Notker, Boethius, De Consolatione philosophiae II, 103)
b. únde síh mít tíu lôsen uuóltôn
and REFL with DEM.INST.SG.N save.INF want.PST.3PL
'and wanted to save themselves with that'

(Notker, Boethius, De Consolatione philosophiae II, 102)

The pronouns are not positionally dependent on the verb and can occur on either side of it. They can establish their own stress domain; whether they interact phonologically with their surroundings cannot be inferred from the literature. There is no allomorphy. The pronouns inflect for person, number, and case, third person sih not distinguishing number. The pronouns can be used to form reciprocals but not passives. An intensifier selb-can be added for emphasis or clarification (Braune and Reiffenstein 2004. 241-242; Dal 2014. 79).

1. positional dependency: FALSE

2. phonological interaction: +STRESS, ?INTERACTION

3. allomorphy: FALSE

4. inflection: +NUMBER, +PERSON, +CASE

5. position: + PRE, + POST

6. equivalence set with + RECIPROCAL, -PASSIVE

7. expandable: TRUE

8. syncretism: ВотH

\subsubsection{Middle High German}

Middle High German, a West Germanic language spoken in present day southern Germany, Switzerland and western Austria between c. 1050 and 1350 CE, retains the personal pronouns and the reflexive sin/sich of Old High German including their usage to encode reflexivity.
a. Si wolten sich erchölen.
they want.PST.3PL REFL cool.INF
'They wanted to cool themselves.'
$\begin{array}{lllll}\text { b. } & \text { def urówete fich der uater gůte } \\ \text { DEM.GEN.SG.N rejoice.PST.3SG REFL ART.NOM.SG father.NOM.SG good.NOM.SG }\end{array}$
'the good father rejoiced about that' (Die altdeutsche Exodus, 0a, 421)
(Die altdeutsche Exodus, 0a, 230) 
The pronouns are not positionally bound and can occur on either side of the verb. There are full, lengthened, and cliticised forms, the former two being able to establish their own dtress domain. The latter phonologically interact with their surroundings. They inflect for person, number, and case, with number syncretism in the third person sch forms. They can form reciprocals but not passives. An intensifier selp can be added to expand the construction (Klein 2009 31, 211-215, 222; Dal 2014. 79).

1. positional dependency: FALSE

2. phonological interaction: \pm STRESS, \pm INTERACTION

3. allomorphy: TRUE

4. inflection: +NUMBER, +PERSON, +CASE

5. position: $+\mathrm{PRE},+\mathrm{POST}$

6. equivalence set with + RECIPROCAL, -PASSIVE

7. expandable: TRUE

8. syncretism: ВотH

\subsubsection{Modern High German}

Modern High German uses the reflexive pronoun sich for the third person, and oblique personal pronouns for the first and second persons.

$$
\begin{aligned}
& \text { Er betrachtet sich (selbst/selber) im Spiegel. } \\
& \text { He observe.PRS.3SG REFL (INT) in.ART mirror.DAT.SG } \\
& \text { 'He looks at himself in the mirror.' }
\end{aligned}
$$

The pronouns are not positionally bound and can occur on either side of the verb. There is no allomorphy. The pronouns can establish their own stress domain and do not interact phonologically with their surroundings. They inflect for person, number, and case, with number syncretism in the third person. They can be used to form reciprocals but not passives. An intensifier selbst/selber can be added to expand the construction for emphasis or clarification (Dudenredaktion 2009. 267-273, 401).

1. positional dependency: FALSE

2. phonological interaction: +STRESS, -INTERACTION

3. allomorphy: FALSE

4. inflection: +NUMBER, +PERSON, +CASE

5. position: + PRE, + POST

6. equivalence set with + RECIPROCAL, -PASSIVE

7. expandable: TRUE

8. syncretism: FALSE 


\subsection{North Germanic}

\subsubsection{Old Norse}

Old Norse, the language spoken in Scandinavia, present-day Denmark, the Faroe Islands, Iceland, wide parts of Britain and Ireland, Normandy, and several other parts of Europe between c. 700 and $1150 \mathrm{CE}$, uses both oblique first and second person and special third person reflexive pronouns (40b-c), and a medio-passive verbal marker (40a) to encode reflexivity.
a. bjó-sk hann pá til hólmg̨ngu
prepare.PST-2/3sG 3SG.M then to duel.GEN.SG
'he then prepared for the duel'
b. Flosi bjó sik austan
F.NOM prepare.PST.3SG REFL from east
'he prepared to go west'
c. at eigi segði hann sik pyrsta
that NEG say.PST.SUBJ.3 3sG.M.NOM REFL thirsty
'that he had not declared himself thirsty'

The medio-passive marker $(-s k 2 / 3 ;-k 1)$ is positioned at the right edge of the verb, is part of the verb's stress domain, and phonologically interacts with it - mainly causing consonant elisions. It inflects for person and number (without third person number syncretism), but not for case. There is no allomorphy. The marker can also be used to express reciprocity and passives.

The pronouns are not dependent on the position of the verb. They can stand right of the verb, but whether they can be positioned to its left does not emerge from the literature. They can establish their own stress domain and do not interact with surrounding material, not showing allomorphy either. The pronouns inflect for person and number (with third person number syncretism); they cannot be used to express reciprocity or passives. Both can be expanded by adding an element sjalf- that inflects for person, number, and case (Haugen 2015 129; Faarlund 2004 123-127; Nedoma 2006 74-75, 134-135).

1. positional dependency: вотн

2. phonological interaction: \pm STRESS, \pm INTERACTION

3. allomorphy: вотн

4. inflection: +NUMBER, +PERSON, \pm CASE

5. position: $-\mathrm{PRE},+\mathrm{POST}$

6. equivalence set with \pm RECIPROCAL, \pm PASSIVE

7. expandable: TRUE

8. syncretism: ВотH

\subsubsection{Danish}

Danish uses the middle voice formed with a former reflexive pronoun sig to denote reflexives.

$$
\begin{aligned}
& \text { a. Han slår sig. } \\
& \text { 3SG.M hit-PRS MP } \\
& \text { 'he gets hurt' }
\end{aligned}
$$

(Herslund 2002; 75) 
b. Han slårr sig selv 3SG.M hit-PRS MP self 'He hits himself'

(Herslund 2002: 75)

The reflexive is always positioned right of the verb and therefore positionally dependent on it. It does not interact phonologically with the verb but cannot establish its own stress domain (but it can be targeted by emphatic stress). There is no allomorphy. The marker inflects for number and person, but not for case; it can't be used to form reflexives or reciprocals. The forms can be expanded - especially in prototypical reflexive contexts - with an intensifier selv (LundskærNielsen and Holmes 2010: 159-187, 343, 346-347; Herslund 2002 74-75; Hvilshøj 1999 Basbøll 2005 88).

1. positional dependency: TRUE

2. phonological interaction:-STRESS, -INTERACTION

3. allomorphy: FALSE

4. inflection: +NUMBER, +PERSON, -CASE

5. position: -PRE, + POST

6. equivalence set with-RECIPROCAL, -PASSIVE

7. expandable: TRUE

8. syncretism: TRUE

\subsubsection{Norwegian (Bokmål and Nynorsk)}

Norwegian Bokmål and Nynorsk use first and second person oblique personal pronouns and third person reflexive pronouns to encode reflexivity.

$$
\begin{aligned}
& \text { Han skynder seg. } \\
& \text { 3sG.m hurries.Prs MP } \\
& \text { 'He is in a hurry.' }
\end{aligned}
$$

(Faarlund, Lie, and Vannebo 1997: 340)

The reflexive pronouns are positioned right after the verb and therefore positionally dependent on it. They do not interact phonologically with surrounding phonological material and can establish their own stress domain. They inflect for number and person, but not for case and they do not display allomorphy. It is not possible to use them to form reciprocals or passives. They may be by expanded by selv (Bokmål) or sjølv (Nynorsk) (cf. Faarlund, Lie, and Vannebo 1997; 340-341; Kristoffersen 2000 333-335).

1. positional dependency: TRUE

2. phonological interaction: +STRESS, -INTERACTION

3. allomorphy: FALSE

4. inflection: +NUMBER, +PERSON, -CASE

5. positioning: -PRE, + POST 
6. equivalence set:-RECIPROCAL, -PASSIVE

7. expandable: TRUE

8. syncretism: TRUE

\subsubsection{Icelandic}

Icelandic, the modern language spoken in Iceland, uses oblique first and second person pronouns and a third person reflexive as well as so-called medium verbal endings to express reflexivity.
a. ég gleðjast
1sG.NOM please.PRS.SG.MP
'I am pleased'
b. ég skammast mín
1SG.NOM be ashamed.PRS.SG 1SG.GEN
'I am ashamed'
c. Sér pvoði María fyrr idag
REFL.3.DAT wash.PST.3SG M.NOM earlier today
'María washed earlier today'
(Kress 1982: 145)
(Kress 1982: 105)
(J. G. Jónsson 2011 109)

The medium ending -st is added at the right edge of the verb (sometimes changing place with the verbal ending, e.g. við köll-um-st við köll-ust-um 'you are called'), being part of the verbs stress domain often fusing with the verbal ending. There is no allomorphy. It does not inflect for person, number, or case; it can be used for the expression of both reflexives and reciprocals.

The pronouns can be positioned on either side of the verb (43b-c) and are not positionally dependent on it. They can establish their own stress domain and do not interact with surrounding material. They inflect for person, number, and case with number syncretism in the third person. There is no allomorphy and the pronouns can't be used to form reciprocals or passives. An element sjálf-inflecting for person, number, and case can be added to expand the construction (Kress 1982 104-105, 143-147; J. G. Jónsson 2011; Pétursson 1978: 95, 116-121).

1. positional dependency: вотн

2. phonological interaction: \pm STRESS, \pm INTERACTION

3. allomorphy: FALSE

4. inflection: \pm NUMBER, \pm PERSON, \pm CASE

5. position: \pm PRE, + POST

6. equivalence set with \pm RECIPROCAL, \pm PASSIVE

7. expandable: TRUE

8. syncretism: вотн

\subsubsection{Faroese}

Faroese, the modern language spoken on the Faroe Islands, uses both a synthetic verbal form (the so-called medio-passive, ex. (44a)) and reflexive pronouns (i.e. oblique pronouns in the first and second persons and reflexive pronouns in the third person) to encode reflexivity (44b). 

a. eg setti-st niður
1SG.NOM sit.PST.SG-MP down
'I sat down.'
b. Hann vaskaði sær
3SG.M Wash.PST.SG REFL.DAT
'He washed'

(Lockwood 1955 135)

(Barnes 2001 69)

The reflexive pronouns are positioned directly right of the verb, but are neither part of its stress domain nor do they interact with it phonologically. There is no allomorphy. It inflects for person and case, and, in the first and second persons also for number. It cannot be used for passives or reciprocals. It can be compounded with sjálv- (agreeing in number and gender with the A-argument and in case with the P-argument) which is in some cases compulsory.

The medio-passive-ending -st is added to the verbal form on its right edge, being part of the verbs stress domain and phonologically interacting with the verb (showing, e.g., elision of consonants or assimilations). It does not inflect for number, person, or case, but can be used to encode both reciprocals and passives (Lockwood 1955 70, 84-85, 115-118, 135-136; Barnes 2001. 65-69 and passim; Práinsson, Petersen, and Lon Jacobsen 2004 119-120, 325-336).

1. positional dependency: TRUE

2. phonological interaction: \pm STRESS, \pm INTERACTION

3. allomorphy: FALSE

4. inflection: \pm NUMBER, \pm PERSON, \pm CASE

5. position: $-\mathrm{PRE},+\mathrm{POST}$

6. equivalence set with \pm RECIPROCAL, \pm PASSIVE

7. expandable: TRUE

8. syncretism: BOTH

\section{Romance}

\subsection{Old French (Francien)}

The Francien dialect of Old French, spoken in the region of present-day Île-de-France between c. 750 and $1300 \mathrm{CE}$, uses oblique personal pronouns and a special third-person reflexive marker to encode reflexivity.
a. Je me deport.
1SG.A 1SG.P amuse.PRS.1SG
'I amuse myself.'
b. Molt quiement le dit
a sei meïsme.
(Einhorn 1974 65)
very quietly 3SG.N Say.PRF.3SG to 3.REFL self
'He said it very quiet to himself'
(Chanson de Roland, C11)

The oblique pronouns are not positionally dependent on the verb and can occur both pre- and postverbally. They can (but need not) establish their own stress domain and interact with surrounding linguistic material, showing vowel elision between unstressed pronouns and following verbs 
with an initial vowel. There seems to be no allomorphy. The pronouns inflect for person, number, and case, showing number syncretism in the third person. They can be used to express reciprocity but not to form passives. An intensifier meïsme can be added to expand the construction (Einhorn 1974 63-70; Ménard 1972 3, 28-40).

1. positional dependency: FALSE

2. phonological interaction: +STRESS, +INTERACTION

3. allomorphy: FALSE

4. inflection: +NUMBER, +PERSON, +CASE

5. position: +PRE, + POST

6. equivalence set with + RECIPROCAL, -PASSIVE

7. expandable: TRUE

8. syncretism: TRUE

\subsection{Old French (Norman, Anglo-Norman)}

The Norman dialect of Old French, spoken in the region of present-day Normandy, the Channel Isles, and, from 1066 onwards, also in England, southern Wales, southern Scotland, and Ireland between c. 750 and $1300 \mathrm{CE}$, uses oblique personal pronouns and a special third-person reflexive marker to encode reflexivity.

$$
\begin{aligned}
& \text { Quil voleit faire a sé aclin } \\
& \text { who.3sg.M want.IPF.3sg do.INF at REFL.3 subjected } \\
& \text { 'who he wanted to subdue' }
\end{aligned}
$$

The oblique pronouns are not positionally dependent on the verb and can occur both pre- and postverbally. They can (but need not) establish their own stress domain and interact with surrounding linguistic material, showing vowel elision between unstressed pronouns and following verbs with an initial vowel. There seems to be no allomorphy. The pronouns inflect for person, number, and case, showing number syncretism in the third person. They can be used to express reciprocity but not to form passives. An intensifier meïsme can be added to expand the construction (Short 2013 130-132; Einhorn 1974: 63-70).

1. positional dependency: FALSE

2. phonological interaction: +STRESS, +INTERACTION

3. allomorphy: FALSE

4. inflection: +NUMBER, +PERSON, +CASE

5. position: +PRE, + POST

6. equivalence set with + RECIPROCAL, -PASSIVE

7. expandable: TRUE

8. syncretism: TRUE 


\subsection{Jersey-Norman/Jèrriais}

Jersey-Norman or Jèrriais, the modern dialect of Norman French spoken on the Channel Isle Jersey, uses cliticised P-markers in the first and second persons, and a special reflexive marker in the third person to express reflexivity. For socio-cultural reasons we assign Jèrriais to the continent.

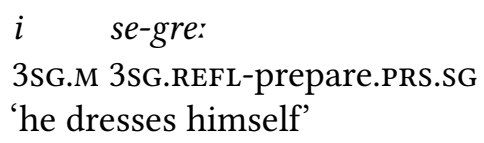

The $\mathrm{P}$ - and reflexive markers are positionally dependent on the verb, being positioned directly to its right with imperatives and directly to its left with all other tense-mood combinations. They are part of the verb's stress domain and phonologically interact with the verb, showing vowel elision and liaison-phenomena with vowel-initial verbs. The variation seen in the third person reflexive marker $s / s e$ is phonological in nature and thus there is no allomorphy. They inflect for person, number, and case. In the third person, singular $s / s e$ can also be used instead of plural $l y$ : As in Standard French, the reflexive formation can also be used to express reciprocals and passives. The forms can be expanded by adding a post-verbal marker me:m, mwe:m (Liddicoat 1994 240-249).

1. positional dependency: TRUE

2. phonological interaction:-STRESS, +INTERACTION

3. allomorphy: FALSE

4. inflection: +NUMBER, +PERSON, +CASE

5. position: + PRE, + POST

6. equivalence set with + RECIPROCAL, +PASSIVE

7. expandable: TRUE

8. syncretism: ВОтн

\subsection{Norman/Normand}

Like Jersey-Norman, mainland Norman, the modern Gallo-Romance variety spoken in Normandy, employs object clitics with special reflexive forms for the third person to express reflexivity.

$$
\begin{aligned}
& i \quad \text { lyz anyi } \\
& \text { 3PL.A 3PL.REFL be bored.PRS } \\
& \text { 'they are bored' }
\end{aligned}
$$$$
\text { (Lepelley 1974 113) }
$$

The markers are bound to the verb, occurring directly to its right after imperatives and to its left in all other tense-mood combinations. They are part of the verb's stress domain and show vowel elision and liaison-phenomena if the verb begins with a vowel. The variation seen in, e.g., 3PL $l y: / l y z$ is purely phonological and the marker thus does not show allomorphy. They inflect for person and number; the third singular marker $s$ can be used instead of the plural marker $l y: l y z$. From the material available to us, it is unclear whether the marker inflects for case or can be used to form passives or reciprocals. Like in Standard French, the reflexive construction can be expanded by a postverbal formant $m \grave{a}_{\dot{e}} m$ (Lepelley 1974. 113-114). 
1. positional dependency: TRUE

2. phonological interaction:-STRESS, +INTERACTION

3. allomorphy: FALSE

4. inflection: +NUMBER, +PERSON, ?CASE

5. position: + $\mathrm{PRE},+\mathrm{POST}$

6. equivalence set with + RECIPROCAL, +PASSIVE

7. expandable: TRUE

8. syncretism: ВотH

\subsection{Ancien Picard}

Ancien Picard ${ }_{4}^{4}$ the Gallo-Romance dialect spoken in present day northern France and southeastern Belgium between c. 1000 and 1350, employs cliticised personal pronouns in the first and second persons and a reflexive pronoun in the third person to express reflexivity.

$$
\begin{aligned}
& \text { f-crô, mi, qu-vous vous moquez dés gens } \\
& \text { 1sG-believe.Prs.1sG 1sG that-2PL 2PL mock.Prs.2PL of.ART.PL people } \\
& \text { 'I myself believe that you are mocking these people' (Flutre 1970 33) }
\end{aligned}
$$

The pronouns are positionally bound by the verb, appearing in the direct object slot to its left in most cases, but to its right with infinitives. They cannot establish their own stress domain and phonologically interact with their surroundings, e.g. showing liaison phenomena. The markers do inflect for number and person (third person si being used for both singular and plural), but not for case. There is no allomorphy. The pronouns can be used to form reciprocals but not passives. The reflexive can be expanded by adding mesme 'self' (Flutre 1970 505-507; Gossen 1970 123-125, 143-146).

1. positional dependency: TRUE

2. phonological interaction:-STRESS, +INTERACTION

3. allomorphy: FALSE

4. inflection: +NUMBER, +PERSON, -CASE

5. position: $+\mathrm{PRE},+\mathrm{POST}$

6. equivalence set with + RECIPROCAL, - PASSIVE

7. expandable: TRUE

8. syncretism: TRUE

\footnotetext{
${ }^{4}$ Due to the scarcity of data, the description of Ancien Picard is in part complemented by its successor Moyen Picard spoken in roughly the same area in the fourteenth to seventeenth centuries.
} 


\subsection{Picard}

Picard, a modern Gallo-Romance variety spoken in northern France, uses cliticised object pronouns in the first and second persons and a cliticised reflexive pronoun $s$ in the third person to express reflexivity.
a. $\quad a-s-l a ̀ f$
3SG.F.A-3.REFL-wash.PRS.3SG
'she washes herself'
b. i-lqe-fqe dü savlõ
'They need soap' $\quad$ (Flutre 1955, 48)

The pronouns are positionally bound to the verb and occur in a fixed slot left of the verb except for imperatives, where they occur in a slot to the right of the verb. There is no allomorphy. Being cliticised to the verb, the pronouns do not bear stress and phonologically interact wit their host. They inflect for person and number (an additional form lqe can be used to distinguish number in the third person), but not for case. As in Standard French, the forms can be used to form passives and reciprocals. For emphasis, a personal pronoun $+m \tilde{e} m$ can be added to the construction (Flutre 1955 48-49; Lebesgue 1984 19-22).

1. positional dependency: TRUE

2. phonological interaction:-STRESS, +INTERACTION

3. allomorphy: FALSE

4. inflection: +NUMBER, +PERSON, -CASE

5. position: $+\mathrm{PRE},+\mathrm{POST}$

6. equivalence set with + RECIPROCAL, + PASSIVE

7. expandable: TRUE

8. syncretism: ВОтн

\subsection{Modern Standard French}

Modern Standard French uses object pronouns in the first and second persons and a special reflexive pronoun in the third person to encode reflexivity.
a. Il se lave.
3SG.M.A 3.REFL wash.PRS.3sG
'he washes'
b. Il ne se trouvait pas de linguiste pour traduire le document. 3SG.M.A NEG 3.REFL find.IPF.3SG NEG of linguist for translate.INF ART document 'You couldn't find a linguist to translate the document.'

(Batchelor and Chebli-Saadi 2011: 321)

c. Alors nous nous battons?

so $1 \mathrm{PL} 1 \mathrm{PL}$ beat.PRs.1SG

'So, we're going to fight, aren't we?' (Guentchéva and Rivière 2007: 583) 
The pronouns are positionally bound by the verb and appear in the direct object position to the left of the verb with most inflected forms and to its right with infinitives. They cannot establish their own stress domain and interact phonologically with the verb, showing liaison phenomena and vowel elisions. There is no allomorphy. The forms inflect for person and number (third person se being used for both singular and plural), but not for case. They can form both passives and reciprocals and can be expanded by adding the formant même (Guentchéva and Rivière 2007; Batchelor and Chebli-Saadi 2011 314-324, 435-451).

1. positional dependency: TRUE

2. phonological interaction:-STRESS, +INTERACTION

3. allomorphy: FALSE

4. inflection: +NUMBER, +PERSON, -CASE

5. position: +PRE, + POST

6. equivalence set with + RECIPROCAL, + PASSIVE

7. expandable: TRUE

8. syncretism: TRUE

\section{Abbreviations}

ÆCH2 Ælfric of Eynsham (1979). Elfric’s Catholic Homilies: The Second Series, Text. Ed. by Malcolm Godden. London: Oxford University Press.

AO Henry Sweet (1883). King Alfred's Orosius. Old-English Text and Latin Original. Vol. 1. London: The Early English Text Society.

B Émile Ernault (1888). Le mystère de Sainte Barbe. Tragédie Bretonne. Texte de 1557 publié avec traduction française, introduction et dictionnaire étymologique du Breton Moyen. Paris: Thorin.

BM Whitley Stokes (1872). Beunans Meriasek. The Life of Saint Meriasek, Bishop and Confessor. A Cornish Drama. London: Trübner.

CD Henry Lewis (1923). "Catwn a'i Ddehongliad. Peniarth Ms. 3, ii; p. 34”. In: Bulletin of the Board of Celtic Studies 2, 8-36.

CW Paula Neuss (1983). The Creacion of the World. A critical edition and translation. New York \& London: Garland.

Eg Finnur Jónsson (1924). Egils Saga Skallagrímssonar. Nebst den grösseren Gedichten Egils. Zweite neu bearbeitete Auflage. Halle (Saale): Niemeyer.

GWV Gwenan Jones (1939-1941). "Gwyrthyeu y Wynvydedic Veir”. In: Bulletin of the Board of Celtic Studies 9.4, 144-148, 334-341 \& 10, 21-33.

Ml. Aaron Griffith and David Stifter (2009-2013). A dictionary of the Old-Irish glosses in the Milan Codex Ambrosianus C 301 inf. Institut für Sprachwissenschaft, Universität Wien. URL: http://www.univie.ac.at/indogermanistik/milan_glosses.htm.

$\mathrm{Nj} \quad$ Finnur Jónsson (1908). Brennu-Njálssaga. Halle a. S.: Niemeyer.

$\mathrm{PH} \quad$ Robert Atkinson (1887). The Passions and Homilies from Leabhar Breac. Dublin: The Academy.

RhGL13 Graham R. Isaac et al. (2010). Rhyddiaith Gymraeg o Lawysgrifau'r 13eg Ganrif. Aberystwyth: Prifysgol Aberystwyth. URL: http://hdl.handle.net/2160/5813 
RMSM Guillaume de Saint-Pair (2009). Le Roman du Mont Saint-Michel. XII siècle. Ed. by Catherine Bougy. Caen \& Ville d'Avranches: Presses Universitaires de Caen \& Scriptorial.

SGGK John R. R. Tolkien and Eric V. Gordon (1925). Sir Gawain and the Green Knight. Oxford: Clarendon.

Wb. Whitley Stokes and John Strachan (1901-1903). “Codex Paulinus Wiziburgensis”. In: Thesaurus Palaeohibernicus. A Collection of Old-Irish Glosses, Scholia Prose and Verse. Vol. 1. Cambridge: Cambridge University Press, 499-712.

\section{References}

Amador-Moreno, Carolina P. (2010). An Introduction to Irish English. London \& Oakville: Equinox. Arfsten, Antje K. and Wendy Vanselow (2014). Friisk tekstsaamling. Fering. Nordfriisk Instituut. URL: http://www.nordfriiskinstituut.de/fering.pdf.

Århammar, Nils (2001). "Das Nordfriesische im Sprachkontakt". In: Handbuch des Friesischen. Handbook of Frisian Studies. Ed. by Horst Haider Munske et al. Tübingen: Niemeyer, 313-353.

Barbour, John (1896). Legends of the Saints in the Scottish Dialect of the Fourteenth Century. Edited from the unique manuscript in the university library, Cambridge. Ed. by William M. Metcalfe. 3 vols. Edinburgh \& London: Blackwood \& Sons.

Barnes, Michael (2001). Faroese Language Studies. Oslo: Novus.

Basbøll, Hans (2005). The Phonology of Danish. Oxford: Oxford University Press.

Batchelor, Ronald E. and Malliga Chebli-Saadi (2011). A Reference Grammar of French. Cambridge: Cambridge University Press.

Beal, Joan (1997). "Syntax and morphology". In: The Edinburgh History of the Scots Language. Ed. by Charles Jones. Edinburgh: Edinburgh University Press, 335-377.

Bickel, Balthasar, Kristine A. Hildebrandt, and René Schiering (2009). "The distribution of phonological word domains: A probabilistic typology". In: Phonological Domains. Universals and Deviations. Ed. by Janet Grijzenhout and Bariş Kabak. Berlin: de Gruyter, 47-75.

Borsley, Robert D., Maggie Tallerman, and David Willis (2007). The Syntax of Welsh. Cambridge: Cambridge University Press.

Braune, Wilhelm and Ingo Reiffenstein (2004). Althochdeutsche Grammatik. Vol. 1: Laut- und Formenlehre. 15th ed. Tübingen: Niemeyer.

Bremmer, Rolf H. (2009). An Introduction to Old Frisian. Amsterdam \& Philadelphia: Benjamins.

Broderick, George (1984). A Handbook of Late Spoken Manx. 3 vols. Tübingen: Niemeyer.

Brückmann, Elke (n.d.). Plattdeutsch-Hochdeutsches Wörterbuch für Ostfreisland. URL: http://www. platt-wb.de/

Buma, Wybren Jan and Wilhelm Ebel (1965). Das Brokmer Recht. Göttingen: Vandenhoeck \& Ruprecht.

Calder, George (1980). A Gaelic Grammar. Containing the parts of speech and the general principles of phonology and etymology with a chapter on proper and place names. Glasgow: Gairm.

Dal, Ingerid (2014). Kurze deutsche Syntax auf historischer Grundlage. 4th ed. Berlin: De Gruyter.

Donaldson, Bruce (2017). Dutch. A comprehensive Grammar. 3rd ed. London \& New York: Routledge.

Dottin, Georges (1913). Manuel d'Irlandais Moyen. 2 vols. Paris: Champion.

Drabek, Irene (2007). Fering. Analyse einer europäischen Minoritätensprache unter dem Einfluss des Deutschen im fahr 2007. Lic. phil., Universität Zürich.

Dudenredaktion, Bibliographisches Institut Mannheim. (2009). Duden - die Grammatik : unentbehrlich für richtiges Deutsch. 8., überarb. Aufl. Mannheim: Dudenverlag. 
Eagle, Andy (2016). An Introduction to Modern Scots. URL: http://www.scots-online.org/articles/ contents/ModernScots.pdf

Ebel, Wilhelm (1968). Das Stadtrecht von Goslar. Göttingen: Vandenhoeck \& Ruprecht.

Einhorn, Elsabe (1974). Old French. A Concise Handbook. Cambridge: Cambridge University Press.

Evans, D. Simon (1964). A Grammar of Middle Welsh. Dublin: Dublin Institute for Advanced Studies.

Faarlund, Jan T. (2004). The Syntax of Old Norse. Oxford: Oxford University Press.

Faarlund, Jan T., Svein Lie, and Kjell I. Vannebo (1997). Norsk referansegrammatikk. Oslo: Universitetsforlaget.

Flutre, Louis-Fernand (1955). Le Parler Picard de Mesnil-Martinsart (Somme). Phonétique, Morphologie, Syntaxe, Vocabulaire. Genève \& Lille: Libraire Droz \& Libraire Giard.

- (1970). Le Moyen-Picard. D’après les textes littéraires du temps (1560-1660). Textes - Lexique Grammaire. Amiens: Musée de Picardie.

Franck, Johannes (1910). Mittelniederländische Grammatik. Mit Lesestücken und Glossar. Leipzig: Tauchnitz.

Gallée, Johan Hendrik (1993). Altsächsische Grammatik. Mit Berichtigungen und Literaturnachträgen. 3rd ed. Berlin \& New York: de Gruyter.

Gelderen, Elly van (2000). A History of English Reflexive Pronouns. Person, Self, and Interpretability. Amsterdam \& Philadelphia: Benjamins.

Gossen, Charles T. (1970). Grammaire de l'Ancien Picard. Paris: Klincksieck.

Guentchéva, Zlatka and Nicole Rivière (2007). "Reciprocal and reflexive constructions in French". In: Reciprocal Constructions. Ed. by Vladimir P. Nedjalkov. Amsterdam \& Philadelphia: Benjamins, 561-607.

Haugen, Odd Einar (2015). Norröne Grammatik im Überblick. Altisländisch und Altnorwegisch. Netzversion. 2nd ed. Übersetzung aus dem Norwegischen von Astrid van Nahl. Bergen: Universität Bergen. URL: http://folk.uib.no/hnooh/Grammatik

Hemon, Roparz (1984). A Historical Morphology and Syntax of Breton. Dublin: Dublin Institute for Advanced Studies.

Herslund, Michael (2002). Danish. München: Lincom Europa.

Hickey, Raymond (2007). Irish English. History and Present-Day Forms. Cambridge: Cambridge University Press.

Hoekstra, Jarich F. (2001). "Standard West Frisian". In: Handbuch des Friesischen. Handbook of Frisian Studies. Ed. by Horst Haider Munske et al. Tübingen: Niemeyer, 83-98.

Huddlestone, Rodney and Geoffrey K. Pullum (2005). A Student's Introduction to English Grammar. Cambridge: Cambridge University Press.

Hvilshøj, Ulrik (1999). "Refelksivitet i dansk. Sig og sig selv i et typologisk perspektiv". In: $N y$ Forskning i Grammatik 6, 81-106.

Irslinger, Britta (2014). "Intensifiers and reflexives in SAE, Insular Celtic and English". In: Indogermanische Forschungen 119, 159-206.

Jónsson, Jóhannes Gísli (2011). "Reflexive sig is an argument". In: Nordlyd. Tromsø University Working Papers on Language and Linguistics 37, 99-118.

Kerckevoorde, Colette M. van (1993). An Introduction to Middle Dutch. Berlin \& New York: de Gruyter.

Kerckvoorde, Colette van (1994). A Descriptive Grammar of Jan Yperman's Cyrurgie. New York etc.: Lang.

King, Anne (1997). "The inflectional morphology of Older Scots". In: The Edinburgh History of the Scots Language. Ed. by Charles Jones. Edinburgh: Edinburgh University Press, 156-181. 
King, Gareth (2003). Modern Welsh. A Comprehensive Grammar. 2nd ed. London \& New York: Routledge.

Klein, Thomas (2009). Mittelhochdeutsche Grammatik. Tübingen: Niemeyer.

Kress, Bruno (1982). Isländische Grammatik. München: Hueber.

Kristoffersen, Gjert (2000). The Phonology of Norwegian. Oxford: Oxford University Press.

Lamb, William (2002). Scottish Gaelic. 2nd ed. München: Lincom Europa.

Lasch, Agathe (1914). Mittelniederdeutsche Grammatik. Halle a. S.: Niemeyer.

Lebesgue, Philéas (1984). Grammaire Picard Brayonne. Amiens: Université de Picardie.

Lepelley, René (1974). "Le parler Normand du Val de Saire (Manche). Phonétique morphologie syntaxe vocabulaire de la vie rurale". $\mathrm{PhD}$ thesis. Caen: Paris X - Nanterre.

Liddicoat, Anthony (1994). A Grammar of the Norman French Dialects of the Channel Islands. The Dialects of Jersey and Stark. Berlin \& New York: de Gruyter.

Lindow, Wolfgang (1998). Niederdeutsche Grammatik. Leer: Schuster.

Lockwood, William B. (1955). An Introduction to Modern Faroese. København: Munksgaard.

Lundskær-Nielsen, Tom and Philip Holmes (2010). Danish. A Comprehensive Grammar. 2nd ed. London: Routledge.

Markey, Thomas L. (1981). Frisian. The Hague, Paris, \& New York: Mouton.

Matras, Yaron and Gertrud Reershemius (2003). Low German. East Frisian dialect. München: Lincom.

Ménard, Philippe (1972). Manuel d'ancien français. 2nd ed. 3 vols. Bordeaux: sobodi.

Mondorf, Britta (2012). "Late Modern English: Morphology". In: English Historical Linguistics. An International Handbook. Ed. by Alexander Bergs. Vol. 1. Berlin \& New York: de Gruyter, 842-869.

Nedjalkov, Vladimir P. (2007). "Encoding of the reciprocal meaning”. In: Reciprocal Constructions. Ed. by Vladimir P. Nedjalkov. Amsterdam \& Philadelphia: Benjamins, 147-207.

Nedoma, Robert (2006). Kleine Grammatik des Altisländischen. 2., erw. und aktualisierte Auflage. Heidelberg: Winter.

Ó Curnáin, Brian (2007). The Irish of Iorras Aithneach, County Galway. 4 vols. Dublin: Dublin Institute for Advanced Studies.

Ó Murchú, Pól (2013). A Grammar of Modern Irish. An Annotated Guide to Graiméar Gaeilge na mBráithre Críostaí. Baile Átha Cliath: Teangaleanga.

O’Rahilly, Cecile (1967). Táin Bó Cúalnge. From the Book of Leinster. Dublin: Dublin Instutue for Advanced Studies.

Pétursson, Magnús (1978). Isländisch. Eine Übersicht über die moderne isländische Sprache mit einem kurzen Abriß der Geschicgte und Literatur Islands. Hamburg: Buske.

Phillips, John D. (2004). Manx. München: Lincom Europa.

Popkema, Jan (2013). Frisian Grammar. The Basics. Leeuwarden: Fryske Akademy.

Quak, Arend (1992). "Versuch einer Formenlehre des Altniederländischen auf der Basis der Wachtendonckschen Psalmen”. In: Zur Phonologie und Morphologie des Altniederländischen. Ed. by Rolf H. Bremmer and Arend Quak. Odense: Odense University Press, 81-123.

Roux, Pierre le (1957). Le verbe breton. Morphologie, syntaxe. 2nd ed. Rennes \& Paris: Pilhon \& Champion.

Schmidt-Petersen, Jürgen and James Craigie (1928). The North Frisian Dialect of Föhr and Amrum. Edinburgh: Hutchen.

Schumacher, Stefan (2011). "Mittel- und Frühneukymrisch". In: Brythonic Celtic - Britannisches Keltisch. From Medieval British to Modern Breton. Ed. by Elmar Ternes. Bremen: Hempen, 85-235. Shetter, William Z. (1993). Dutch. An Essential Grammar. 7th ed. London \& New York: Routledge. Short, Ian (2013). Manual of Anglo-Norman. 2013: Anglo-Norman Text Society. 
Stenson, Nancy (2008). Basic Irish: A Grammar and Workbook. London \& New York: Routledge.

Stifter, David (2010). "Early Irish". In: The Celtic Languages. Ed. by Martin J. Ball and Nicole Müller. 2nd ed. London \& New York: Routledge, 55-116.

Thomas, Peter W. (1996). Gramadeg y Gymraeg. Caerdydd: Gwasg Prifysgol Cymru.

Thurneysen, Rudolf (1946). A Grammar of Old Irish. Revised and enlarged edition. Dublin: Dublin Institute for Advanced Studies.

Tiersma, Peter M. (1985). Frisian Reference Grammar. Dordrecht \& Cinnaminson: Foris.

- (1999). Frisian Reference Grammar. 2nd ed. Ljouwert: Fryske Akademy.

Timm, Lenora A. (1987). "The verb morphology of Carhaisien Breton". In: Zeitschrift für Celtische Philologie 42, 242-292.

Toorians, Lauran (2014). Towards a Grammar of Middle Cornish. Version 1.1. uRL: http://laurantoorians. com/?page_id=128

Walker, Alastair G. H. and Ommo Wilts (2001). "Die nordfriesischen Mundarten”. In: Handbuch des Friesischen. Handbook of Frisian Studies. Ed. by Horst Haider Munske et al. Tübingen: Niemeyer, 284-304.

Williams, Nicholas J. A. (2011). "Middle and Late Cornish". In: Brythonic Celtic - Britannisches Keltisch. From Medieval British to Modern Breton. Ed. by Elmar Ternes. Bremen: Hempen, 237357.

Wmffre, Iwan (1998). Central Breton. München: Lincom Europa.

- (1999). Late Cornish. München \& Newcastle: Lincom Europa.

Práinsson, Höskuldur, Hjalmar P. Petersen, and Jógvan í Lon Jacobsen (2004). Faroese. An Overview and Reference Grammar. Tórshavn: Føroya Fróðskaparfelag. 